Öneri, C.2, S.7.

Haziran, 1997, ss.67-70.

\title{
SPOR VE SALDIRGANLIK
}

\author{
Dr. Ayşe ATALAY \\ M. ̈. Beden Eğitimi ve Spor Y.O., Yardımcı Doçent.
}

\begin{abstract}
Aggressiveness, is a reactional behavior defined as an objective of causing harm in a physical or physchological way to its enemies and competitions as a result of inducement. Aggressiveness in sports are divided into two parts such as aggressiveness within the game and aggressiveness of spectators. Aggressiveness in sports don't spread out within time. All of a sudden show itself. Aggressiveness in sports is in a way equipped. Because sports are in the direction of significant objectives such as representation of our country in the best way and getting the highest degree and also becoming a champion etc.
\end{abstract}

\section{I-GIRIŞ}

Uzmanlar, 21.yüzyıla damgasını vuracak olan iki olgudan söz etmektedir. Bunlardan biri 21.yüzyllın bilgi ve enformasyon toplumu,diğeri de serbest zaman toplumu olacağı öngörüsüdür. Bu bağlamda spor olgusu gelecekte karşımıza özellikle endüstrileşmiş ülkelerde teknoloji, serbest zaman,medya üçgeni içinde en başta yer alacaktır. Çalışma saatlerinin kısaltılması,teknolojik yenilikler özellikle bilgisayanın günlük yaşamımıza girmesi,refah düzeyinin artması gerçekten serbest zamanın toplumda bugünkünden daha fazla bir önem ve ağırlık kazanmasına yol açacaktır. Almanya'da Serbest Zaman Enstitüsü tarafindan 1981'de yapllan bir araştırmada 1975 'de her yll için 2.010 saat serbest zaman öngörülüyorken,bu oran 1980 yilında 2.100 saate çıkmış ve 1990 yilında da 2.400 saate ulaşması beklenmektedir[1]. Böylece insanlar serbest zamanlarını değerlendirmede spora daha fazla yer verecekler,bu da gerek bireysel gerekse kolektif düzlemde sporun insan yaşamında giderek daha fazla bir yer kaplamasına yol açacaktır. Insanlar sportif faaliyetlerle daha çok bir araya gelecekler, birbirlerini ulusal ve uluslararası platformda daha yakından tanıma firsatı elde edeceklerdir. Ancak bu karşılıklı etkileşim her zaman barışçı bir platformda gerçekleşmeyecektir. Başka bir deyişle insanlik henüz ilişkilerinde saldırganlığı dışlayan siyasal, kültürel ve ekonomik düzeye ulaşamadığından sporda saldırganlık, uzun bir süre varlığını koruyacaktır. Burada spor ve saldırganlık arasındaki ilişkiye girmeden önce saldırganlık kavramının tanımını yapmak istiyorum.

\section{II-SALDIRGANLIK KAVRAMI NEYI IÇERMEKTEDİR?}

Saldırganlık, bir uyaran sonucu düşmanına ya da rakiplerine fiziksel veya psikolojik olarak zarar vermek amacını güden tepkisel bir davranış biçimidir. $\mathrm{Bu}$ bağlamda Yves Michaud ise saldırganlığı şöyle tanımlamaktadır:

"Bir karşllıklı ilişkiler ortamında taraflardan biri ya da bir kaçı doğrudan veya dolaylı, toplu veya dağınık olarak, diğerlerini bir veya bir kaçının bedensel bütünlügüne veya törel (ahlaki), moral (manevi) bütünlüğüne veya mallarına veya simgesel ve sembolik ve kültürel değerlerine,oranı ne olursa olsun zarar verecek şekilde davranırsa, orada şiddet vardir".[2] Şiddet eylemi bir kerede olabildiği gibi zamana yayılmış olarak da gerçekleşebilir. Birincisinde şiddet eylemi, ikincisinde şiddet durumu söz konusudur. Birisini doğrudan öldürmek şiddet eylemi, açlıktan ölmeye terketmek ise şiddet durumunu gösterir. Sporda karşılaştığımız şiddet ise, daha çok şiddet eylemi içine girer. Çünkü bir kerede vuku bulur, zamana yayılmamıștır. Sporda saldırganlık da "normlardan, doğal, olağan veya yasal olarak nitelendirilen durumlarda uygulanan yönetim kurallanndan uzaklaşma anlamını içerir..."[2]

O halde bir davranışın saldırgan bir davranış olup olmadığı niyet ile yakından ilgilidir. Sporda da saldırgan davranışın niyetle yakından ilişkisi vardır. Niyet, oyunun kurallarını aşıyorsa sporda saldırganlıktan söz edebiliriz. Bir boks maçında rakibi yumruklamak oyunun kuralı olmasına karşın, bir futbol karşılaşmasında rakibi yumruklamak cezayı gerektirir. Sporda karşılaşılan saldırganlık iki platformda gerçekleşir.

1-Oyun içi saldırganlık.(Oyunu oynayanlann saldırganlığı)

2-Seyirci saldırganlığı. 
Oyun içi saldırganlık. oyuncuların rakiplerine ya da hakeme karşı giriştikleri saldırgan davranışlardır. Seyirci saldırganlığ ise ya hakeme. ya rakip takımın oyuncularına ya da rakip takımin taraftarlarına yöneliktir.

Yapılan bir araştırmaya göre[3] futbol maçlarında hakemin kararına küfürle karşıllı veren scyircilerin oram \% 37.8 gibi büyük bir orandadır. Kendilerine anket uygulanan seyircilerin $\% 34$ 'ü ise çoğu kez. hakeme küfrettiklerini belirtmişlerdir. Yine aynı araştırmaya göre futbol maçlarında karşı lakımın futbolcuları sert futbol oynadığı zaman saluạa yabancı madde atanların oranı \% 39 gibi önemli bir boyultadır. Araştırmaya katılanların \% 1t'ü de çoğu zaman sahaya yabancı madde atıklarını belirtmişlerdir. Futbol maçlarında karşı takımın oyuncularmı ankete katılanlarm \% $39^{\prime} 6$ sl çoğu kez dövme isteği duyduklarını. \% 29'3 lük bir kesim ise bazen böyle bir arzu duyduklarmı. \% It'5 ise daima böyle bir istek taşıdıklarını belirtmişlerdir.

\section{III-SALDIRGANLIK KAVRAMI NEYI IÇERMEKTEDIR?}

Saldırganlık. bir uyarı sonucu düşmanına ya da rakiplerine fiziksel ya da psikolojik olarak zarar verıme amacını güden tepkisel bir davranış biçimidir. Bu bağlamda Yves Michaud ise şiddeti, şọyle tammlamaktadir:

"Bir karşılıklı ilişkiler ortamında taraflardan biri ya da bir kaçı doğrudan veya dolaylı, toplu veya dağınık olarak diğerlerine, bir veya bir kaçının bedensel bütünlüğüne veva törel(ahlaki). moral(manevi) büıünlüğüne veya mallarma veya simgesel ya da sembolik veya kültürel değerlerinc. oranı ne olursa olsun zarar verecek şekilde davranırsa. orada şiddet vardır."[3]. Șiddet eylemi bir kerede olabildiği gibi zamana yayılınış olarak da gerçekleşebilir. Birincisinde şiddet cylemi. ikincisinde șiddet durumu söz. konusudur. Birini doğrudan öldürmek şiddet cylemi. açlıktan ölmeye terketmek ise şiddel durumunu gösterir. Sporda karşılaştığımız şiddet ise. daha çok şiddel eylemi içine girer. Çünkü bir kerede vuku bulur. Zamana yayılmamıștır. Sporda saldırganlık da "normlardan, doğal ya da olağan veya yasal olarak nitelendirilen durumlarda uygulanan yönetim kurallarından uzaklaşına anlamını içerir...[4].

\section{IV-SALDIRGANLIĞIN NEDENLERI}

Saldırganlığın nedenlerini üç grupta toplamak olanaklıdır:

I-Biyolojik (içgüdüsel).

2-Psikolojik.

3-Sosyo-kültürel ve sosyo-ekonomik.

1-Bazı bilim adamları(Freud.Lorenz.Mc Dougall) insanın doğarken saldırganlık dürtülerini de beraberinde getirdiğini öne sürmüşlerdir. Freud'a göre. insan davranışlarına iki unsur yön verir. Bunlardan biri yapıcı cinsel enerji olan libido, diğeri ise saldırganlık enerjisi thanatosdur." Bu içtepiler içe dönük olarak etkinleştiklerinde, insanların enerjilerini kısıtlamalarına, kendilerini cezalandırmalarına. mazohistik olmalarma ve aşırı durumlarda intihar etmelerine neden olurlar. Dışa dönük olarak etkinleştiklerinde ise. saldırgan, savaşımcı davranışlarda anlatım bulurlar". [5].

Sporda kendine yönelik saldırganlık ender olarak görülmekle birlikte. hiç rastlanmayan bir durum da değildir. Geçtiğimiz Mart ayında Fenerbahçe'nin Trabzonspor'la beraberliğine katlanamayan Fenerbahçe'li bir bayan taraftarın kendini Boğaz köprüsünden atarak intihar elme girişiminin güçlükle engellendiği hala bellcklerdedir. Daha gerilere gidersek 1948 yilında Türk Milli Takımmın Yunan Milli takımın 3-1 gibi bir skorla ycnmesi üzcrine Yunan'lı bir seyircinin üzüntüsünden intihar ettiğini belirtebiliriz.

Lorenz'e göre ise saldırganlık, insan doğasımın kendisinde vardır. İnsanda saldırganlık içgüdüsü depolanmış bir durumda bekler. Bundan ötürü ona göre "saldırganlık. esas olarak dış uyaranlara karşı bir tepki değil. insanm içinde gömülü serbest kalmaya çabalayan ve dış dürtülerin yeterli olup olmamasına bakmaksizın anlatımını bulacak olan uyarıdır"|4]. Görüyoruz. ki saldırganlı̆̆ı içgüdüsel olarak açıklayan görüşlere göre. saldırganlığa yol açan bir neden olarak bir uyarıcının olması gerekmez. Bu bakımdan içgüdüsel saldırganlık kuramını değerlendirmek güçtür. Hayvanlarda olduğu gibi insanlarda da saldırganlığın içgüdüsel olduğunu kanıtamanın en iyi yolu saldırganlık duygularına yol açabilecek tüm uyaranların ortadan kaldırılması olurdu ki bu da insanın tam bir izolasyon içinde yetiştirilmesi demektir. Ayrıca insanı bu şekilde hayvani içgüdülerinin tuısağı olarak görmek. akılla donatılmış bir varlığı gereğinden fazla küçümsemek demektir.

$$
\text { 2-Saldırganlık olgusumun en önemli }
$$
nedenlcrinden biri de psikolojiktir. Burada engelleme 
boyutu önem kazanmaktadır. "Engelleme, bir amaca ulaşınanın engellenmesi ya da yavaşlatılmasıdır" $|6|$. Burada. amaçlanan dünya ile yaşanılan dünya arasındaki farklılık söz konusudur. Tuttuğu takımın yenilmesi. taraftar için bir engelleme duygusu oluşturabilir. Rakip takımın oyuncusuna kural dışı davranışlarda bulunmak, rakip takımun seyircisine çirkin sözler söylemek ve davranışlarda bulunmak. onlara saldırmak, verdiği kararlardan ötürü engelleme unsuru olarak görülen hakeme çirkin tezahüratlarda bulunmak sporda engellemeden doğan saldırganlığa örnek oluşturur. Ancak engelleme her zaman şiddete yol açmaz. Eğer engelleme. takımın kötü oyun oynamış olması gibi haklı bir nedene dayalı olarak görülüyorsa. her zaman saldırganlığa yol açmaz. Yani bireyin bir durumu algılama ve yorumlama biçimi, onun engelleme ve saldırılara tepkisini de etkilemektedir. Bu durumda bir huzursuzluktan söz edilemez. Engellemede isc bir huzursuzluk vardır." Saldırı(şiddet). doğrudan doğruya huzursuzluğun kaynağına yönelir. $\mathrm{O}$ da yasaklanmışsa dolaylı saldırganlıklar ya da öznenin kendi kendine giriştiği saldırganlık hareketleri görülmeye başlar..."[7].

"Dışa yönelik saldırı. amaç ve hedefi arasındaki uyumluluk açısından ikiye ayrılır...[8]. Bunlardan biri "tepkisel saldırganlık", diğeri ise "araçsal saldırganlık" dır. Tepkisel saldırganlıkta hedef ve amaç arasında bir paralellik vardır. Burada tahrik unsuru önemlidir. Bu durumda saldırı ya kişiyi tahırik edene karşı doğrudan ya da yön değiştirmiş olarak dolaylı bir biçiınde ortaya çıkar. Araçsal saldırganlıkta ise güdülen amaç. daha çok ön plandadır. Ülkesini en iyi şekilde temsil etmek. derece clde etmek. şampiyon olmak gibi.

3-Sporda saldırganlığın bir başka boyutu da sosyolojiktir. Başka bir deyişle toplumun içinde bulunduğu sosyo-ekonomik ve sosyo-kültürel özelliklerin spora saldırganlık biçiminde yansımasıdır. Sosyal, siyasal ve ekonomik dengelerini iyice oturtamamış toplumlarda spor karşılaşmalarında ortaya çıkan saldırganlık, "dağınık siyasal-toplumsal şiddet"in bir başka görünümüdür. Bunlar genellikle aniden patlak verirler, iyi örgütlenmemișlerdir. $\mathrm{Bu}$ tür olaylarda yaşama duyulan güvensizlik önemli bir yer tutar. Gelecek kaygısı. yaşam pahalılı̆̆ı, işsizlik, sosyal uçurumlar bu tür saldırganlığı besleyen unsurlardır. Yani güncel toplumsal koşullar da saldırganlı̆̆ı teşvik edici bir unsur olmaktadır. Örneğin futbol fanatizmni 1980'lerin İngiltere'sinde en ciddi kamu sorunlarından biri olarak ele alınmaktadır. "Bu konu, ișsizliğin amansız yükselişi, sürekli arttığı iddia edilen serserilik olayları, şiddet ve suç oranı ve özellikle de ișçi sınıfı teenagerleri (12-19 yaş) arasında olmak üzere, ağır uyuşturucuların kullanımındaki arıș ile aynı sırada ele alınıyor... [7]. Örneğin Trivizas(1980), yaptığ1 bir çalışmada futbol fanatiklerinin sosyal durumlarım incelemiş ve bunlardan yüzde sekseninden fazlasınm ya el emekçisi ya da işsiz oldukları sonucunu çıkartmıștır. Yerel. ulusal ve etnik kimlikler de sporda şiddeı kullanımının bir nedeni olmaktadır. Burada diğer bir etken de saldırganlığın toplumsal kültür içinde normatif olarak onaylanma derecesidir. Bu durumda saldurganlık kuşaktan kuşağa aktarılan bir kültür sorunu olarak ortaya çıkıyor. Bu bakımdan saldırganlığı onaylama ya da onaylamama derecesi bir toplumun sosyal karakteri ile yakından ilgilidir.

Yukarıda spor ve saldırganlık arasındaki ilișkiyi nedensellik bağlamında ele almaya çalıştım. Ancak saldırganlık. bir bakıma sporun doğasında vardır. Ne var ki sporun doğasındaki saldırganlık, meşrudur. Bir düzeni ifade eder. normatiftir. "...Bir örnek verelim. Boks maçı da. bir sokak kavgası da insanların bir başka kişiyi yumrukla incitmesidir. Fakat karşlıklı organizasyon ortamları ve tanıkların tepkileri bakmmindan özünde farklı olaylardır. Ve nasıl boks maçında olayın gelişimini belirleyen gayet kesin kurallar varsa. boğa güreşinde de matador ve yardımcıları boğayı. seçtikleri her hangi bir biçimde yok edemezler. Her iki olayda da kurallar gerçekte düzeni gözetmek için lasarlanır.rckabetin nitcliğini tanımlar ve simrlar..."[7]. Oyundaki saldırganlık. yıkıcıllk ve nefrete dönüşmeyen saldırganlıktır. Belirli normlara bağlanmış. meşru bị saldırganlıktır. Amaç yok etmek değil beceri göstermektir. "Oyun ölümle sonuçlanırsa bu. rakibin yanlıs yerde durmasından doğar"... [9].

\section{V-SONUC}

Bedenimiz.sosyal bir form: sosyal bir ifade biçimidir. Bedenimizin sosyal bir olgu olarak ifade edildiği spor da sosyal bir kurumdur. Yani sosyal bir yapıda organize edilir ve uygulanır. Yenen veya yenilenin nasıl oynadığı,yenen ya da yenilene gösterilen tepki biçimleri, toplumun sosyal, kültürel. ekonomik yapısından bağımsız düșünülemez. Sporda barbarlığı önlemenin yolu ise spor olgusunun toplumdan soyutlanamayacağının, bu alanda yaşanılan patlamaların birikmiş ve çözülmemiş sosyo-ekonomik ve sosyokültürel sorunların çözülmeleri gerektiğine ilişkin sosyąl bir uyarı olduğunun bilincine varılımıs olmasında yatar. Spor. ancak bu şekilde barışçı. dostluklan ve karşılıklı anlaỵışı pekiştirici bir işlev kazanır. Bu da şiddeti spordan dışlamak amacımın gerçekleşmesi açısından toplumların her alanda yeniden yapılanmasını gerekli kılmaktadır. Bu açıdan bakıldığında spor bir bakıma yenileşmedir de. 


\section{KAYNAKÇA}

[1]. Prof. Dr. Josef HACKFORTH, Freizeit, Sport, Medien, Akademieschrift, No: 33, Führungs und Verwaltungs Akademie Berlin des Deutschen Sportbundes e.V. 1984, s.3.

[2]. Yves MICHAUD, Şiddet, çev: Cem Muhtaroğlu, İletişim Yayınları, 1991, s.11.

[3]. Çimen ONLÜCAN, <Türk Futbol Seyircisinde Saldırganlık ve Nedenleri<, 1996,s. 67.

[4]. J.L. FREEDMAN, et al., Sosyal Psikoloji, çev: Prof.

Dr. Ali Dönmez, Imge Kitabevi, 1993, s.240.

[5]. Erich FROMM, İnsandaki Yıkıcılı̆ın Kökenleri, çev: Şükrü Alpagut, Payel Yayınevi, 1993, s. 38.

[6].Can IKIZLER, Sporda Başarının Psikolojisi, Alfa Yayınevi, 1994, s. 74

[7]. Elisabeth Copet ROUGIER, Antropolojik Açıdan Şiddet, çev: Dilek Hattatoğlu, Ayrıntı Yayınlan, 1989, s. 203.

[8]. Erich FROMM, Sevginin ve Şiddetin Kaynağı, çev: Yurdanur Salman / Nalan İçten, Payel Yaymevi, 1990, s. 23

[9]. Erich FROMM, Sevginin ve Şiddetin Kaynağı, çev.

Yurdanur Salman/ Nalan İçten, Payel

Yaymevi, 1990, s.21. 